\title{
American culture-specific items designating status: Translation aspects
}

\author{
Liudmyla Slavova ${ }^{1}$, Natalia Borysenko ${ }^{2 *}$, and Dariia Demenchuk ${ }^{3}$ \\ ${ }^{1}$ Taras Shevchenko National University of Kyiv, Ukraine \\ ${ }^{2}$ Zhytomyr Ivan Franko State University, Zhytomyr, Ukraine \\ ${ }^{3}$ Collegium Civitas, Warsaw, Poland
}

\begin{abstract}
The study deals with culture-specific items denoting the status of a person in the novel Gone with the Wind by Margaret Mitchell and its translations into Ukrainian and Russian. The paper focuses around lexemes that functioned during and after the Civil War and nominated the inhabitants of the USA according to their background, political and religious views, social layer, occupation, ethnic or Afro-American identity. Structuring cultural knowledge is manifested in the cultural code, which is verbalised due to the use of the abovementioned groups of words denoting status in the novel under study. With the view to the specificity of the time described, the novel abounds in culture-specific items that cause difficulty in Ukrainian and Russian translations, thus presupposing the translator's striving for either preservation of the historical epoch in the target text or its substitution with the features of contemporary life. The translation techniques applied are transcoding; borrowing from the English or other European languages; descriptive translation (explicitation); literal translation; neutralization; approximate translation; the use of translational doublets; contextual translation; omission. Research results contribute to the development of cultural translation which studies specific differences of source and target texts with the respect both to the source and target cultures.
\end{abstract}

\section{Introduction}

The research deals with the culture-specific items which represent historically and culturally specific information in the novel Gone with the Wind by M. Mitchell [1] and their rendering in Russian and Ukrainian translations.

The novel written in 1936 describes the time of the Civil War in the United States in the 60 es of the $19^{\text {th }}$ century. The Ukrainian translation accomplished by Rostyslav Dotsenko [2], who was a famous Ukrainian translator and literary critic, was published in 1992. The Russian translation prepared by Tatiana Ozerskaya [3], a renowned Russian translator, was published for the first time in 1982. Thus both Ukrainian and Russian translations were meant for the readers, who, on the one hand, belong to a different culture, and, on the other hand, are separated from that time by more than a hundred years.

\footnotetext{
${ }^{*}$ Corresponding author: nat.dbor@gmail.com
} 
As the novel creates a bright panorama of life in the Southern states at one of the most crucial periods in the history of the South, there are a number of cultural, historical, and archaic words that are associated with the life of the period and help the writer to create the atmosphere of the time and the place. The mentioned above lexical units may denote the phenomena that have already become obsolete, do not exist in the life of the American community, and it is quite natural that they, to a certain extent, may not be clear to the contemporary readers not only in the United States, but also in other countries and their understanding presupposes some specific knowledge of the history of the country. In the novel there are archaic words, which denote phenomena that are still present in the life of American community, but have already acquired a different name. When it comes to the readers outside the American community, cultural, historical, and archaic words are difficult to understand as they acquire not only the historical colouring as it is in the case with American readers, but also a cultural one. The subject of our study is lexical items that denote social status of a person, were in use during this epoch described in the novel and require special techniques in translation. We define status as an individual's position, often relative to others, in a group or society as characterized by certain benefits and responsibilities as determined by an individual's rank and role [4].

The research aim is to classify culture-specific items designating the status of a person in the novel Gone with the Wind and the techniques used in rendering them in Ukrainian and Russian translations. The objectives set include: to define culture-specific items designating status; to classify them; to single out techniques applied to render such items in translation; to evaluate translators' techniques in terms of preserving the pragmatic effect of the original text and the historical epoch.

\section{Theoretical Background}

Translating a historical novel there arises a dilemma - to represent the phenomena, which do not exist at present, and to render the words, denoting notions, that are no longer in use. In his paradoxes of translation T. H. Savory points out an important demand put to the translation of the fiction that describes the past epochs specifying that the target text should read as a contemporary of the original and a contemporary of the translator, i.e. the target reader at the same time [5: 49]. On the other hand, in a historical novel lexical, morphological and syntactical archaic forms aim at creating a special stylistic effect of a definite epoch [6: 142]. Hence, the problem faced by the translators is whether to bring the translated text closer to their own time and target cultural community ignoring historical and archaic words or use corresponding words of the target language in order to preserve the atmosphere of the epoch reflected in the original text. After all, there is another option when both approaches are combined and balanced. This is especially important, as the shift to the excessive use of archaisms and historicisms in the translation can make the text absolutely obscured, whereas omitting the lexical units mentioned above will deprive the text of its historical and cultural flavour and colouring.

There exists a well-established tradition connected with the research of culture-specific items in fiction in Ukrainian [7, 8] and foreign translation theory [9], but the problem is far from being solved as there is no unanimity even as to the term itself. Bulgarian and PostSoviet theories of translation studies are based on the notion of realia, Ukrainian реалія, Russian реалия [10], whereas American, Asian and Western European traditions offer a number of terms, such as cultural words [11], culture-bound problems [12], culture-bound concepts [13], culture-specific terms [14], culture-specific items [15]. What unites different approaches is the thought that cultural information is one of the sources of untranslatability [16] and is a challenge for translators. 
We argue that historical culture-specific items employed by the writers in fiction comprise the cultural code, which is defined as a way of structuring cultural knowledge [17: 20], a set of images and ideas that are ethnically and culturally determined and are verbalized by means of a language in the literary work. The translator's task is to render the cultural code without distorting it. The latter is problematic, as the receiver can impose his or her own artistic language on the source text and re-code it [18:25] in the process of translation.

When it comes to culture-specific items representation in translation, notwithstanding their low translatability [19: 223], there exists a definite tradition to render them in translation with the help of transcoding or borrowing, calque, description, approximation, transformation [20:7], renomination [7], adaptation [21] to compensate for the lack of equivalence [16: 73].

Most culture-specific items in a historical novel are represented by archaisms and historicisms that reflect the atmosphere of the epoch where the scene is laid. Such lexical units can be used in order to render the corresponding items of the source text or they can be applied in the contexts when there are no archaisms and historicisms in the source text.

Research methods of the paper comprise textual analysis aiming at specifying the structure of the source and target texts; contextual analysis helping to define the historical and cultural atmosphere of the source text; translational analysis allowing to single out techniques used by the translators while rendering culture-specific items in Ukrianian and Russian; the analysis of dictionary definitions making it possible to identify the meaning of the culture-specific items in the source text and the lexemes used to render them in the target texts; contrastive analysis enabling us to state the differences in the process of presentation of culture-specific items in English, Ukrainian and Russian.

\section{Results and Discussion}

The culture-specific items denoting status of a person in the novel Gone with the Wind verbalise the cultural code of the text. In this study we differentiate the lexical units naming people, mainly the inhabitants of the USA, according to their background, political and religious beliefs, social layer, occupation, ethnic and Afro-American identity.

As the novel describes the struggle of the North and the South from the point of view of the Southerners, the author uses nominations of the inhabitants of these regions. For example, the negatively coloured lexeme Yankee, which at the time described in the novel had the meaning of a native or inhabitant of the northern U.S. [22], actualizes the semes 'place of birth' and 'place of living'. It is used in the novel to describe those who were associated with the North: And anyway, the Yankees are too scared of us to fight [1: 7].

The item Yankee is rendered in the Ukrainian translation with the help of transcoding: $I$, крім того, янкі занадто бояться нас, цоб напасти [2: 8]. In fact, the word янкі is present in the online dictionary of the foreign words and in its first meaning is labeled as Назва жителів Нової Англії у ХVІІІ столітті [23]. The Russian language borrowed the lexeme янки in the meaning of уроженец или житель Новой Англии (северовосточных штатов США) [24: 945]. As it is seen from the dictionary definitions the Ukrainian borrowed lexeme янкі has the semes 'place of living' and 'time', whereas the Russian equivalent demonstrates the presence of the semes 'place of living', 'place of birth' being nearer in meaning to the English lexeme. The technique of transcoding is found in the Russian target text as well: Да и вообще, янки слишком боятся нас, чтобы решиться с нами воевать [3: 19]. Thus, in both translations the technique of transcoding is applied and the borrowings which have already entered the Ukrainian and Russian dictionaries of the foreign words are used. 
It should be noted that there are cases when the item Yankee of the original text is translated into Ukrainian and Russian with the help of stylistically neutral lexemes північани and северяне correspondingly, as in the following example: But now the Confederate ports were stoppered with Yankee gunboats... [1: 144]; Але тепер порти Конфедерачії блокував флот північан... [2: 156]; Но теперь, когда военные корабли северян блокировали порты конфедератов... [3: 140]. Native Ukrainian word північани means мешканці півночі [25: 384], whereas Russian северянин is interpreted as уроженеи или житель севера [26: 697], thus both lexemes have the seme 'place of living', although the Russian lexeme additionally actualizes the seme 'place of birth' corresponding more to the meaning of the English lexeme Yankee which has both semes as well. In this case, the stylistically neutral synonym implements the technique of neutralisation, although the meaning of the source lexeme is preserved. In fact, English lexeme Northerner is labeled as a native or resident of the northern part of the U.S. [22]. Thus, dictionary definitions of the words Yankee and northerner coincide. So, the Ukrainian північани and Russian северянин сan be translational doublets of the Ukrainian янкі and Russian янки.

The inhabitants of the Southern states are called in the novel in a number of ways. The most neutral lexical item is Southerner defined in the dictionary as especially : a native or resident of the southern part of the U.S. [22]. For example: And she thinks Southerners are barbarians [1: 17].

In the Ukrainian translation the word Southerner is rendered with the help of the native Ukrainian item південці, which has a meaning of мешканці півдня [25: 379]: I щее при тому думає, щзо ми, південиі, - варвари [2: 20]. The Russian translation offers an equivalent южанин - уроженеи или житель юга [26: 902]: И при этом она ведь считает нас, южан, дикарями [3: 28]. The analysis of the dictionary definitions demonstrates that both English Southerner and Russian южанин characterize a person according to the place of birth and the place of living, while Ukrainian південиі identifies a person only according to the place of living. At the same time, the English word restricts the place of birth or living to the United States only, whereas Ukrainian and Russian lexemes do not indicate it. Hence, in both translations literal or direct translation with the help of a native lexeme of the target language takes place.

Another term used is Confererate - an adherent of the Confederate States of America or their cause [22]. As it comes from the definition the word names a person according to their political beliefs. In the novel the lexeme Confederate designates also those who served in the Confederate Army: The Confederates marched in their sleep, too tired to think for the most part [1: 291].

In both Ukrainian and Russian target texts the technique of transcoding is applied to render the lexical unit Confederate(s) with the addition of the typical Ukrainian (конфедерати) and Russian (конфедераты) suffixes of the plural form $-u$ and $-b l$ respectively: Через нескінченні переходи конфедерати не мали коли й виспатись і були здебільшого такі втомлені, щзо їм ніякі думки не йшли до голови [2: 313]. Конфедераты спали на ходу, слишком измученнье, чтобы о чем-нибудь думать [3: 272]. In the original text there is no gender marked special term for a woman supporting the Confederate States, as in the case, when the speech of an undereducated Belle Wayling is imitated by Melanie: Ain't I a Confedrut, good as you? [1: 244]. Anyhow, in both translations we find the gender marked nomination of a Confederate woman, i. e. Ukrainian конфедератка and Russian конфедератка with the suffix of the feminine gender $-\kappa a$ : Хіба я не така сама конфедератка, як $і$ ви? [2: 266], Я тоже конфедератка, и может, почище вас! [3: 233].

At the same time, in the Ukrainian language the word конфедерати is associated with the history of Poland, as it comes from the dictionary definition: $У$ феодальнокріпосницькій Польщі учасники конфедерацій [27]. The dictionary definition labels 
Russian конфедерать - в Польше в 16-18 вв. - участники конфедерации [24: 394] in a similar way. In both translations the borrowing from a Western Slavic language which has a different meaning from the English lexeme Confederate, but is identical in form is applied. Nevertheless, in the target Ukrainian and Russian texts of the novel the meaning of Ukrainian конфедерати and Russian конфедераты is clear from the context of the novel.

It should be noted that the translators also use the technique of explicitation in order to translate the item Confederate as in the following context: Atlanta read, knew the oracle had spoken, and as loyal Confederates, they hastened to cast Rhett out [1: 233]. The Russian translator in this context chooses the word-combination верная Конфедерации meaning those who are loyal to Confederacy, where конфедерация - форма государственного устройства, при которой государства, образующие конфедерацию, сохраняют независимость (суверенитет) и объединяются для координации нек-рых своих действий (внешнеполитических, военных и др.) [24: 394]: Атланта прочла письмо, вняла вещаниям своего оракула и, верная Конфедерации, поспешила выливырнуть Ретта Батлера вон [3: 222]. However, the Ukrainian translator preserves the equivalent конфедерати used in the meaning of supporters of Confederacy: Атлантці прочитали ці слова свого знаного оракула $i$, як чесні конфедерати, поспішили викинути Батлера геть [2: 253].

Political views are also reflected in the nomination Orangeman which is connected with the political life of Northern Ireland, but finds its followers in the USA as well. The lexeme is described as a member of a secret society organized in the north of Ireland in 1795 to defend the British sovereign and to support the Protestant religion [22]. For instance: There was no Orangeman this side of hell worth a hundred pounds to the British government or to the devil himself [1: 43]. The Ukrainian translation uses a borrowed via Russian French word orangiste: Жоден ще не запроторений у пекло оранжист не вартий був ані в очах британського уряду, ані навіть в очах диявола ста фунтів стерлінгів [2: 47-48] combined with explanatory translation in the footnote where the translator gives the definition of the term: Оранжистами в Ірландіï називають з кіния XVII cm. англошотландських колоністів-протестантів. Первісно так звалися прибічники Вільгельма Оранського, який у битві над р. Бойн у Північній Ірландії 1690 р. переміг Якова (Джеймса) II з династії Стюартів і став відтоді англійським королем [2: 48]. The Russian variant is restricted to the use of a borrowed from French lexeme: Ни один оранжист, еще не отправленный в ад, не стоил в глазах британского правительства, да и самого сатаны, ста фунтов стерлингов [3: 52] creating а problem with the interpretation of the term.

Religious beliefs are reflected in the lexeme Mormon, which is labeled in the dictionary as a member of a religious group called the Church of Jesus Christ of Latter-Day Saints, which began in the US in 1830 [28]. In the original text Beatrice Tarlton uses the nomination addressing her twin sons who both court Scarlett O'Hara, hinting at the fact that Mormons practice polygamy: Then you'll have to move to Utah, if the Mormons'll have you [1: 17].

In the Ukrainian target text transcoding (тоді вам доведеться перебратися в Юту до мормонів - хоч я не певна, чи вони вас приймуть [2: 19]) is combined with descriptive translation and the technique of explicitation in the footnote: Мормони - члени релігійної секти, яка тривалий час визнавала багатоженство. Штат Юта - одне з основних місиь їх розселення [2: 19], which clarifies for the Ukrainian reader the hint of Beatrice Tarlton. The Russian variant does not give any explanation as to the Mormons' practice of polygamy: тогда вам придется переселиться в Юту, к мормонам... если только они вас примут [3: 28]. Furthermore, the explanatory dictionary of the Ukrainian language specifies the properties of the denomination beliefs: У Північній Америці члени релігійної секти, віра яких є сумішшю християнства та багатобожжя [29: 
803], the same is found in dictionary of the Russian language: Североамериканская секта, учение к-рой представляет собою смесь многобожия и христианства [30: 261]. Thus, Russian readers should look the item мормон up in a specialized source, otherwise the hint is lost upon them.

Social division in the Southern states is represented by a number of words and word combinations. Several nominations are connected with poor white inhabitants of the South. Lexeme Cracker is defined in the dictionary as offensive - used as an insulting and contemptuous term for a poor, white, usually Southern person or sometimes offensive: a native or resident of Florida or Georgia —used as a nickname [22]. For example: but the boys had less grammar than most of their poor Cracker neighbors [1: 6]. As it is seen from the context the lexeme Cracker has negative connotation. The Ukrainian translation fully ignores it: але щзодо граматики, то ичих двійко хлопців пасли задніх навіть порівняно $з$ більшістю свої білих сусідів з незаможного фермерства [2: 8], choosing descriptive translation and the technique of neutralisation, giving no hint to the offensive character of the original nomination, but specifies the race, type of property and status: білі сусіди 3 незаможного фермерства. The Russian target text: но по части грамматики близнець уступали большинству своих небогатых соседей - «голодранцев», как называли бельх бедняков на Юге [3: 18] offers a negatively coloured approximate equivalent голодраниьы used in the inverted commas combined with the technique of descriptive translation, as the race and status are identified как называли бельх бедняков на Юге. The dictionary definition labels голодранец as low colloquial and contemptuous (nрост. презр.) оборванеи, бедняк [26: 133].

Another negatively coloured nomination white trash is defined in the dictionary as usually disparaging + offensive : a member of an inferior or underprivileged white social group [22]. For example: Do you mean to compare him with real white trash like the Slatterys? [1: 9]. In the Ukrainian translation a native Ukrainian lexeme голодранеиь Убога людина; бідняк [31: 114] is used: Що ти його рівняєш до таких, як Слеттері ось вони справжні голодраниі [2: 22]. The Russian translation has a noun шваль which is labeled in the dictionary as low colloquial and derogatory (прост пренебр.) негодный, ничтожный человек, люди, рвань [26: 881]. For example: Tын не равняй его с такой, $к$ примеру, швалью как Слэттери [3: 30].

The nomination defining the nobility is found in the description of Scarlett's mother, who is called a Coast aristocrat of French descent [1: 5]. The name makes it clear that she belonged to the upper class, her ancestors came from France, and she was brought up near the sea as the word coast is defined in the dictionary as the land next to or close to the sea [28]. Nevertheless, the full understanding of the phrase Coast aristocrat comes if you are acquainted with the geography of Georgia which is bordered to the southeast by the Atlantic Ocean. Later on in the source text it is specified that Ellen was brought up in Savannah [1: 56], which makes the notion of a Coast aristocrat clear to the reader. In the Ukrainian translation we find a phrase аристократки франиузького роду з надбережжя [2: 6], the meaning of which can be lost upon the Ukrainian reader as it is not clear what special meaning should be attached to the analogues lexeme надбережжя which in Ukrainian means смуга землі вздовж берега [32: 62]. As it is seen from the dictionary definition Ukrainian надбережжя can be attributed to any body of water, thus, this technique of approximate translation can be misleading. In the Russian translation местной аристократки франиузского происхождения [2: 17] the word Coast is substituted with the adjective местный - здешний, не приезжий, не привозной [26: 344] which does not give the idea of the aristocracy coming from the Atlantic Ocean Coast. Moreover, this variant can be also misleading as the scene is laid in northern Georgia and according to the dictionary definition of the adjective местный Ellen O'Hara should be perceived by Russian readers as a native of northern Georgia. 
The novel has the nouns that name occupations of white inhabitants of the South. For example, the lexeme trapper which is labeled in the dictionary as in American English a person who traps; esp., one who traps fur-bearing animals for their skins [33] is used in the following context: son of a swamp trapper [1: 20]. Both Ukrainian (сина трапера 3 болотяної долини [2: 23]) and Russian (сын старого траппера [3: 31]) translations apply the technique of transcoding. Besides, Russian mpannep is labeled in the dictionary of foreign words as охотник на пушного зверя в Сев. Америке, пользующииися чаще всего западнями [24: 797], the definition makes it clear that the occupation does not exist outside the USA and, hence, the word is unknown outside American culture.

Another item nominating the occupation of the inhabitants of Georgia is planter, defined in the dictionary as the owner of a plantation [33]: But rich planters were few in the young county of Clayton [1:21]. In the Ukrainian (Але в молодій окрузі Клейтон багатих плантаторів було малувато [2: 23]) and Russian (Но в молодом графстве Клейтон богатых плантаторов было не так много [3: 31]) translations the word planter is rendered with the help of the equivalent плантатор. The latter has the same meaning both in Ukrainian (власник плантації [25: 563]) and in Russian (владелец плантации [26: 511]) and evidently came into the Eastern Slavic languages from Latin via Polish [34: 427].

The names of the local Indian tribes including the Cherokees, where Cherokee is $a$ member of an American Indian people originally of Tennessee and North Carolina [22] are also found in the source text. For example, northward beyond that stream the land was still held by the Cherokees [1: 48]. Both Ukrainian: землі на північ від иієї річки ще заселяють індіанці-черокі [2: 53] and Russian: земли к северу от этой реки еще заселены индейцами племени чероки [3: 55] target texts use the technique which combines explanatory translation and transcoding. The difference lies in the degree of completeness of additional information.

The nominations of Afro-American slaves include a noun negro which is archaic and offensive in Modern English: dated, now often offensive : a person of black African ancestry [22]. In Ukrainian and Russian there exists a word негр / негр, which is a borrowed lexeme in the Eastern Slavic languages coming from Latin niger 'black' [34: 63]. The dictionary of the Ukrainian language defines негри as назва корінного населення тропічної Африки, яке має темний колір шкіри і належить до негроїдної раси, а також нащадків африканиів-негроїдів, примусово переселених у XVI-XIX cm. 6 Америку [32: 280] and Russian негры as люди, принадлежащие к негроидной расе [26: 395].

In the source text the item negro is used in different contexts, for example: the Tarletons owned a hundred negroes [1: 19]. In the translation the nomination can be substituted by a contextual equivalent as in the Ukrainian variant Тарлтони володіли цілою сотнею рабів [2: 22], or rendered by the lexical equivalent негр: Тарлтонь владельиы сотни негров [3: 30]. Another substitution of the equivalent lexeme негр is found when in Russian the adjective чернокожий combined with a noun naming a person is used when rendering the word negro of the source text. For example: Beside her perched the bow-legged little negro who had trained her horses [1: 482]; Кривоногий, малоросльий чернокожий малый - объездчик лошадей - сидел с ней рядом [3: 440]. In this context the Ukrainian translation preserves the equivalent негр: Поруч з нею примостився клишоногий малоросток-негр, колишній об'̈̈ждчик коней [2: 515].

Adjective darky combined with nouns denoting a person is also used in the original text to name Afro-Americans: Stuart halted, too, and the darky boy pulled up a few paces behind them [1: 13]. The Ukrainian and Russian translations use the lexeme негр combined with the noun specifying the age and the gender of the person: Стюарт теж пристав, a трохи віддалік - i хлопчина-негр [2: 15]. Следом за ним остановился и Стюарт. Мальчишка-негр остановился в некотором отдалении [3: 24]. 
In the direct speech of the characters Afro-Americans are nominated with the help of the noun darky which is offensive and used as an insulting and contemptuous term for a black person [22] is found: You darkies know everything that goes on [1: 14]. The insulting character of the lexeme is reflected in the translations under analysis where the technique of approximation is applied. The Ukrainian translator chooses the noun чорнюк derived from the adjective чорний: від вас, чорнюків, не сховаєшся [2: 16]. In the Russian translation we find the lexemе черномазыи in the meaning of colloquial, disapproving dark-skinned and dark-haired [26: 869]: У вас, черномазых, всегда ушки на макушке [3: 25]. So, both translations preserve the insulting character of the English lexeme using approximate equivalents.

One more adjective black in the combination with nouns denoting age and gender is used in the source text in reference to Afro-Americans: she called to the little black girl who carried her basket of keys [1: 10]. Both Ukrainian and Russian translations use a lexeme дівчина-негритянка and девочка-негритянка respectively: вона сказала щось дівчиниі-негритяниі, яка носила за нею кочика з ключами [2: 12] подзывавшей девочку-негритянку, носивщую за ней корзиночку с ключами [3: 22].

Word combinations with the adjective black include stylistically coloured black wench, where wench in one of its meanings is defined as a lewd woman [22]. The above-mentioned word-combination is found in the speech of white Southerners: They promised all the black wenches silk dresses and gold earbobs [1: 439]. The analysis of the target texts shows that the Ukrainian translation uses the form of the Female Gender чорнючка of the noun чорнюк, which allows preserving the derogative character of the lexeme wench: Наобіияли чорнючкам шовкових суконь та золотих сережок [2: 470]. The Russian translation, however, applies the noun негритянка, which at the time, when the translation was made, did not show any negative connotation: Они наобещали негритянкам шелковых платьев да золотых сережек [3: 402].

Afro-American characters use the lexeme nigger which is offensive; used as an insulting and contemptuous term for a black person [22]: "Huccome po' w'ite trash buy any niggers? [1: 19]. Both target texts, however, use partial equivalents, lexemes негри / негры, which at the time of translation did not bear negative connotation in both Ukrainian and Russian: Та відки иуі білі голодраниі наберуть на негрів грошей? [2: 21]. Да откуда у такой нищей белой швали возьмутся деньги покупать себе негров? [3: 30], thus the loss of stylistic colouring leads to neutralization in both translations.

There are cases when in the original text there is no indication of the race, whereas the translators use the lexemе негр as a partial equivalent. For example, ...where Ellen would ration out the food to the home-coming hands [1: 10]; ...де Еллен щзовеора роздавала харчі неграм [2: 12]; ...где Эллин ежевечерне по окончании полевых работ раздавала пищу неграм [3: 22].

Culture items denoting Afro-American servants are presented by several items in the source text. For instance, a specific item mammy names an Afro-American woman-slave who acts as a nanny for the children of the masters. The dictionary of the English language defines mammy as a black woman serving as a nurse to white children especially formerly in the southern U.S. [22]. For example: Mammy felt that she owned the O'Haras [1:24].

In the Ukrainian target text the native lexeme мамка, which is archaic, and means нянька, годувальниия [29: 615] presents a partial equivalent of the culture-specific item татту: Мамка вважала себе верховодою иілої родини О’Гар... [2: 6]. The Russian translation uses the item мамушка, which is archaic and is diminutive from мамка [35] in the meaning of кормилица, нянька [26: 333]: Мамушка считала всех О'Хара своей непререкаемой собственностью [3: 34].

Other nominations of servants include names of male occupations valet described in the explanatory dictionary as a man's male servant who performs personal services (such as 
taking care of clothing) [22] and butler defined in the dictionary as the chief male servant of a household who has charge of other employees, receives guests, directs the serving of meals, and performs various personal services [22]. For instance: As valet, he kept Gerald's bedroom in order, and, as butler, he served the meals with dignity and style [1: 52].

The Ukrainian target text renders the nominations of the servants, applying the technique of approximation and the use of a partial equivalent лакей (defined in the dictionary as слуга у панів або при ресторані, готелі [29: 438]) when it comes to the item valet and the technique of omission when it comes to the lexeme butler, concentrating on the duties performed: Як лакей, кімнату Джералда він тримав у належній чистоті й охайності, і за столом прислуговував гідно і вправно [2: 58].

In the Russian translation we find the partial equivalent of the valet the word лакеи Слуга в господском доме или в гостинице, ресторане [26: 312] and the lexical equivalent of the noun butler дворецкий - в богатом доме: старший слуга, заведующий домашним хозяйством и прислугой [26: 150]: Своими обязанностями лакея он, правда, не пренебрегал, содержал комнату Джералда в порядке и прислуживал за столом умело и с достоинством, как заправский двореикий [3: 60]. Thus, in the Russian translation we find an approximate and literal translations of the two lexemes in question.

\section{Conclusions}

The analysis of the historical culture-specific items denoting social status in the source text of the novel Gone with the Wind by M. Mitchell and their rendering in the target texts in Ukranian and Russian makes it clear that such items play a significant role in creating a historical atmosphere in the source and target texts. The research proves that culturespecific items denoting status are divided into those naming the inhabitants of the USA according to their background, political and religious views, social stratification, occupation, ethnic or Afro-American identity. The above mentioned lexemes verbalise the cultural code of the novel. The problems with their representation in the translations are connected with the fact that they do not always have direct correspondences in the languages of the target texts. As a result, the translator resorts to a number of translation techniques, such as transcoding and borrowing from the English or other European languages alone or combined with descriptive translation (elicitation); literal translation with the help of a native lexeme of the target language; descriptive translation (explicitation); the loss of stylistic colouring, neutralization; approximate translation with the help of a partial equivalent; the use of the translational doublet; contextual translation, and omission. The research proves that in the majority of cases the Ukrainian and Russian translations demonstrate the choice of the similar techniques, the rare differences lie in the fact that the Ukrainian variant strives for the description combined with transcoding in order to make the meaning clearer to the reader, whereas the Russian variant is limited by transcoding alone. Besides, there are cases when one of the translations shows neutralisation and the loss of the stylistic effect, whereas the other manages to preserve it.

The further perspectives of the study are connected with defining the specifics of the translation techniques used in rendering historical culture-specific items from Ukrainian into English.

\section{References}

1. M. Mitchell, Gone with the Wind (Pan Books and Macmillan, London \& Sydney, 1975) 
2. M. Mitchell, Gone with the Wind (Dnipro, Kyiv, 1992)

3. M. Mitchell, Gone with the Wind (Khudozhestvennaja literatura, Moscow, 1991)

4. Free Online Sociology Dictionary, URL: https://sociologydictionary.org/words/s/

5. T. H. Savory, The Art of Translation (J. Cape, London, 1957)

6. V. S. Vinogradov, Introduction to Translation Studies (General and Lexical Issues) (Izdvo In-ta Obshch. Sred. Obraz. RAO, Moscow, 2001)

7. R. P. Zorivchak, Realia and Translation (a Case Study of the English-Language Translations of Ukrainian Prose) (Vydavnytstvo Lvivskoho universytetu, Lviv, 1989)

8. K. Podorozhna, Topical Issues of Humanitarian Sciences 14, 151-156 (2015)

9. D. Blažyte, V. Liubiniene, Kalbų Studijos / Studies about Languages 29, 42-57 (2016)

10. S. Vlakhov, S. Florin, Untranslated in Translation (Mezhdunarodnyje otnoshenija, Moscow, 1980)

11. P. Newmark, A Textbook of Translation (Prentice Hall International, New York, 1988)

12. B. Nedergaard-Larsen, Perspectives: Studies in Translatology 2, 207-241 (1993)

13. D. Robinson, Becoming a Translator: An Accelerated Course (Routledge, London \& New York, 1997)

14. H. Kim, J. Kim, Meta: Translators' Journal 60 (2), 350-350 (2015)

15. J. F. Aixelá, Culture-Specific items in Translation, in R. Álvarez, M. C.-Á. Vidal (eds.), Translation, Power, Subversion (Multilingual Matters LTD, Clevedon, 1996)

16. I. C. Narváez, J. M. Valverde Zambrana, The Journal of Specialised Translation 21, 71112 (2014)

17. V. A. Maslova, Cultural Linguistics (Academia, Moscow, 2001)

18. Ju. Lotman, The Structure of the Artistic Text (Univ. of Michigan Press, Ann Arbor, 1977)

19. J. Horbačauskiene, R.Kasperavičiene, S. Petronoene, Social and Behavioral Sciences 231, 223-228 (2016)

20. N. Ababilova, I. Usachenko, Movoznavstvo 2 (28), 4-9 ( 2017)

21. L. Molina, A.H. Albir, Meta: Translators' Journal 47 (4), 498-512, (2002)

22. Dictionary by Merriam-Webster, URL: https://www.merriam-webster.com

23 Dictionary of Foreign Words, URL: https://www.jnsm.com.ua/cgibin/u/book/sis.pl?Qry=\%FF\%ED $\%$ EA $\%$ B3

24. Great Illustrated Dictionary of Foreign Words: 17000 Words (AST, Astrel, Russian Dictionaries, Moscow, 2004)

25. I. K. Bilodid, Dictionary of the Ukrainian Language. Volume 6: P-POITY (Naukova dumka, Kyiv, 1975)

26. S. I. Ozhegov, N. Ju. Shvedova, Explanatory Dictionary of the Russian Language: 80000 Words and Idioms ("AZ", Moscow, 1995)

27. O. S. Melnychuk, Dictionary of Foreign Words (Ukrainska Radianska Entsyklodediia, Kyiv, 1974) URL: https://ev.vue.gov.ua/wp-content/uploads

28. Cambridge Free English Dictionary and Thesaurus, URL: https://dictionary.cambridge.org/dictionary/

29. I. K. Bilodid, Dictionary of the Ukrainian Language. Volume 4: I-M (Naukova dumka, Kyiv, 1973) 
30. D. N. Ushakov, Explanatory Dictionary of the Russian Language. Volume 2 LOJALOVET (Gosudarstvennoje Izdatelstvo Inostrannykh i Natsjonalnykh Slovarej, Moscow, 1938)

31. I. K. Bilodid, Dictionary of the Ukrainian Language. Volume 2: G-Zh (Naukova dumka, Kyiv, 1971)

32. I. K. Bilodid, Dictionary of the Ukrainian Language. Volume 5: N-O Naukova dumka, Kyiv, 1974)

33. Collins Free Online Dictionary, URL: https://www.collinsdictionary.com

34. O. S.Melnychuk, I. K.Bilodid, V. T. Kolomijets, O. B. Tkachenko, et.al., Etymological Dictionary of the Ukrainian Language, Volume 4: N-P (Naukova Dumka, Kyiv, 2003)

35. T. F. Jefremova, New Dictionary of the Russian Language. Explanatory-Derivational (Russkij Jazyk, Moscow, 2000), URL: https://www.efremova.info 